\title{
HUBUNGAN GRANDPARENTING STYLE TERHADAP KESEJAHTERAAN PSIKOLOGIS LANSIA DI GABUNGAN ORGANISASI LANSIA
}

\author{
Latifah Suci Saraswati ${ }^{1 *}$, Hamiyati $^{1}$, Mulyati ${ }^{1}$ \\ ${ }^{1}$ Program Studi Pendidikan Kesejahteraan Keluarga, Fakultas Teknik, Universitas Negeri Jakarta, \\ Jakarta Timur 13220, Indonesia \\ *E-mail: latifahsucisaraswati@gmail.com
}

\begin{abstract}
Abstrak
Penelitian ini bertujuan untuk mengetahui hubungan grandparenting style dengan kesejahteraan psikologis lansia di Gabungan Organisasi Wanita (GOW) Kota Magelang, Jawa Tengah. Pengumpulan data dilakukan pada bulan Januari 2020 dengan metode survei dengan pendekatan korelasional. Populasi pada penelitian ini adalah lansia yang berusia 64-74 tahun dengan jumlah sampel sebanyak 54 responden yang terdiri atas lansia wanita (nenek). Penentuan sampel pada penelitian ini menggunakan metode non-probability sampling dengan teknik pengambilan data menggunakan teknik sampling jenuh. Pengumpulan data menggunakan instrumen Grandparenting Style (32 butir) dan intrumen Kesejahteraan Psikologis (16 butir). Uji hipotesis data yang digunakan adalah korelasi koefisien product moment. Hasil analisis data menunjukkan $r_{\text {hitung }}>r_{\text {tabel }}$ yaitu sebesar $\left(r_{\text {hitung }} 0,452>r_{\text {tabel }} 0,2262\right)$. Hasil uji t dengan taraf signifikan 0,05 diperoleh $t_{\text {hitung }}>t_{\text {tabel }}$ yaitu $\left(t_{\text {hitung }} 3,65>t_{\text {tabel }} 1,675\right)$ dapat disimpulkan bahwa terdapat hubungan yang kuat dan signifikan antara grandparenting style dengan kesejahteraan psikologis lansia.
\end{abstract}

Kata Kunci: grandparenting style, kesejahteraan psikologis, lansia

\section{The Relationships of Grandparenting Styles Towards Psychological Well-Being in elderly ages at Gabungan Organisasi Wanita (GOW)}

\begin{abstract}
This research aims to determine the relationship of grandparenting styles towards psychologicall well-being in elderly ages. The researcher collecting data for this research at 2020, January using survey method and correlational approach. The populations in this research was elderly, elderly groups aged 64-74 year old with total sample of 54 respondent consisting grandmother. The determination of the number of samples in this research using non probability sampling method with data collection techniques using saturated sampling techniques. The data were collecting using the Grandparenting Style Scale (16 items) and Psychological Well-Being Scale (32 items). The results of data analysis show $r_{\text {count }}>r_{\text {table, }}$, namely $\left(r_{\text {count }} 0,452>r_{\text {table }} 0,2262\right)$. The results of the $t$ test with a significance level of 0,05 obtained $t_{\text {count }}>t_{\text {table }}$, namely $\left(t_{\text {count }} 3,65>t_{\text {table }} 1,675\right)$, it can be concluded that there is a strong and significant relationship between grandparenting styles and psychological well-being.
\end{abstract}

Keywords: elderly, grandparenting style, psychological well-being

\section{PENDAHULUAN}

Keluarga merupakan unit terkecil di dalam masyarakah yang terdiri dari suami, istri, dan anak yang saling berinteraksi dan memiliki ikatan, hubungan darah, atau pernikahan. Keluarga memiliki peranan yang sangat penting dalam upaya terjalinnya komunikasi dan hubungan yang baik diantara ayah dan ibu; ayah dan anak; serta ibu dan anak atau keluarga inti (nuclear family) agar tercapainya keluarga yang kondusif. Perawatan yang penuh kasih sayang 
terhadap anak, pendidikan tentang nilai-nilai kehidupan, baik agama maupun sosial budaya merupakan faktor yang kondusif utnuk mempersiapkan anak menjadi pribadi dan anggota masyarakat yang sehat. Keluarga juga merupakan institusi (lembaga) yang dapat memenuhi kebutuhan insane, terutama kebutuhan bagi pengembangan kepribadian dan pengembangan ras manusia (Syamsu, 2006:10).

Keluarga secara umum terdapat pembagian peran penting dari masing-masing anggota keluarga, ayah sebagai kepala keluarga dan pencari nafkah dan ibu menangani urusan rumah tangga. Kondisi keluarga di Indonesia sangat bervariasi, tidak sedikit pasangan orang tua bekerja yang memutuskan untuk menggunakan nanny atau baby sitter untuk membantu mengasuh anak mereka ketika mereka sedang bekerja. Selain menggunakan nanny atau baby sitter terdapat salah satu dari anggota keluarga luas atau extended family yang dapat membantu mengasuh anak, yaitu kakek dan nenek.

Pengasuhan yang dilakukan oleh kakek dan nenek terhadap cucunya biasa disebut dengan grandparenting. Menurut Brook dalam Arismanto, 2008:163 mengemukakan bahwa figur kakek-nenek (grandparents) menjadi pengasuh utama bagi anak-anak yang penuh tanggung jawab dalam menggantikan tugas orangtua. Bentuk-bentuk pola asuh orangtua sangat erat hubungannya denga kepribadian anak setelah menjadi dewasa. Hal ini dikarenakan ciri-ciri dan unsur watak seseorang yang telah dewasa sudah diletakkan benihnya sejak masih kanak-kanak. Apabila pola-pola yang diterapkan orang tua keliru, maka yang akan terjadi bukannya perilaku yang baik, bahkan akan mempertambah buruk perilaku anak (Koentjaraningrat, 1997:5).

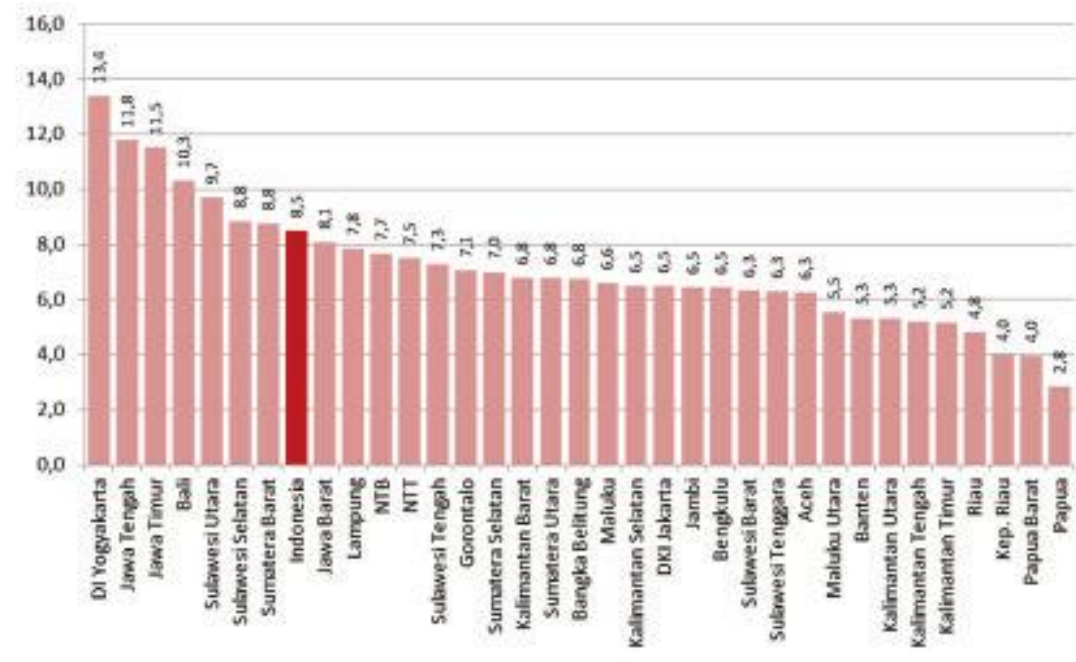

Gambar 1 Persentase Estimasi Penduduk Lansia di Indonesia tahun 2015 (Sumber: Pusat Data dan Informasi, Kemenkes RI

Persentase estimasi penduduk lansia diatas, menunjukkan bahwa persentase lansia terbanyak di Indonesia pada tahun 2015 adalah di kota Yogyakarta sebesar 13,4 persen . Suatu wilayah disebut berstruktur tua jika persentase lansia lebih dari 7 persen . Jika dilihat sebaran penduduk lansia menurut provinsi, persentase penduduk lansia di atas 10 persen ada di provinsi D.I. Yogyakarta (13,4 persen), Jawa Tengah (11,8 persen), Jawa Timur (11,3 persen) dan Bali (10,3 persen). Lansia yang hidupnya bermakna adalah orang-orang yang menerima serta memiliki sikap positif dan tenang dalam menjalani masa tua. Seseorang yang memiliki kesejahteraan psikologis yang tinggi akan lebih merasakan kepuasan dan kebahagiaan secara psikologis dalam hidupnya.

Kota Magelang merupakan salah satu daerah kabupaten atau kota yang terletak di tengah wilayah Kabupaten Magelang, sebelah Utara berbatasan dengan Kecamatan Secang, 
sebelah Timur dengan Kecamatan Tegalrejo, sebelah Selatan dengan Kecamatan Mertoyudan dan sebelah Barat dengan Kecamatan Bandongan. Wilayah Kota Magelang terbagi atas tiga kecamatan, yaitu Kecamatan Magelang Utara, Kecamatan Magelang Tengah, dan Kecamatan Magelang Selatan dengan luas wilayah berturut-turut adalah $6,3037 \mathrm{~km}^{2}$, $5,1011 \mathrm{~km}^{2}$, dan 7,1315 $\mathrm{km}^{2}$ (BPS Kota Magelang, 2018). Penduduk Kota Magelang berdasarkan proyeksi penduduk tahun 2017 sebanyak 121.673 jiwa yang terdiri atas 59.864 jiwa penduduk laki-laki dan 61.809 jiwa penduduk perempuan (BPS Kota Magelang, 2018). Berdasarkan proyeksi penduduk Kota Magelang tahun 2010-2020 sesuai dengan pembagian umur lansia berdasarkan WHO (World Health Organization) yakni lansia dimulai dari usia 45 tahun ke atas, jumlah lansia di Kota Magelang adalah 40.950 jiwa. Peningkatan jumlah penduduk lansia sejalan dengan peningkatan usia harapan hidup. Angka harapan hidup penduduk Indonesia berdasarkan data Biro Pusat Statistik pada tahun 1968 adalah 45,7 tahun, pada tahun 1980 adalah 55,30 tahun, serta tahun 2000 adalah 64,05 tahun (BPS, 2000 diacu dalam Mulyati,2012:2).

Peningkatan jumlah lansia salah satunya disebabkan oleh meningkatnya tingkat pengetahuan masyarakat. Tingkat pengetahuan akan memberikan kesejahteraan bagi para lansia baik dari kondisi psikis maupun kondisi fisik lansia. Peningkatan jumlah lansia akan membawa dampak bagi kesejahteraan psikologis dari diri lansia. Kesejahteraan psikologis lansia bisa di dapatkan dari mengasuh cucu. Pengasuhan yang dilakukan oleh kakek atau nenek dapat menimbulkan kebahagiaan yang dirasakan oleh grandparents. Dalam menjalankan peran grandparenting, terdapat pola interaksi berbeda yang dapat terjadi antara nenek dengan cucu, yang mana disebut sebagai grandparenting style. Grandparenting style dapat diklasifikasikan oleh seberapa sering kontak yang terjadi antara nenek dengan cucu, dan jumlah pengaruh yang dapat diberikan nenek kepada cucu.

Peneliti melakukan studi pendahuluan di Kantor Pusat GOW (Gabungan Organisasi Wanita) Kabupaten/Kota Magelang, Jawa Tengah untuk mengetahui apakah lansia pada organisasi tersebut melakukan pengasuhan cucu melalui karakteristik yang berbeda dari setiap grandparenting style pada tanggal 22 Januari 2018. Peneliti melakukan wawancara langsung dengan Ketua dari GOW (Gabungan Organisasi Wanita) Ibu Sri Rejeki Sulistiyono menurut beliau sebagian besar lansia yang berada di organisasi ini tinggal dengan cucunya dan memiliki kedekatan yang sangat baik dengan cucunya. Jika GOW mengadakan kegiatan rutin atau mengadakan acara-acara khusus untuk para anggota, mayoritas lansia yang berada di organisasi GOW membawa serta cucunya. Namun, ada juga lansia yang tinggal jauh dari cucunya sehingga jarang bertemu langsung dan melakukan interaksi bersama.

Berdasarkan pemaparan di atas, maka dapat dilihat bahwa dengan adanya karakteristik yang berbeda dari setiap grandparenting style, maka dapat memberikan sumbangan yang berbeda terhadap kesejahteraan psikologis individu karena faktor emosi merupakan hal yang penting dalam kesejahteraan psikologis. Oleh sebab itu, peneliti bermaksud untuk melihat hubungan kesejahteraan psikologis ditinjau dari pengadopsian grandparenting style yang berbeda.

\section{METODE}

Dalam penelitian ini, penulis menggunakan kuantitatif asosiatif yang bertujuan untuk mengetahui pengaruh antara dua variabel atau lebih (Sugiyono, 2012: 20). Hasil analisisnya dibahas dalam bentuk uraian hubungan grandparenting style dengan kesejahteraan psikologis lansia. Metode penelitian yang digunakan adalah metode survei dengan pendekatan korelasional yang bertujuan untuk mendapatkan data dari tempat tertentu yang alamiah (bukan buatan), tetapi peneliti melakukan perlakuan dalam pengumpulan data, misalnya dengan mengedarkan kuesioner. Sedangkan pendekatan korelasional untuk menentukan hubungan antar variabel (Sugiyono, 2010: 6). Alasan digunakannya metode survei dengan pendekatan korelasional adalah untuk menentukan variabel mana yang berkorelasi, mencari 
ada tidaknya kaitan antara variabel grandparenting style dan kesejahteraan psikologis lansia, serta untuk mengetahui seberapa serta kaitannya variabel tersebut. Penelitian ini dilakukan di Sekretariat Gabungan Organisasi Wanita (GOW) Kota Magelang, Jawa Tengah. Alamat di Jalan Soekarno Hatta No. 18, Sawitan II, Sawitan, Mungkid, Magelang, Jawa Tengah. Lokasi ini dipilih karena berdasarkan hasil studi pendahuluan yang peneliti lakukan bahwa pada organisasi tersebut mayoritas anggota lansia yang memiliki cucu membawa cucunya pada saat kegiatan organisasi dan mengganggu berjalannya kegiatan organisasi. Selain itu diketahui pula di Provinsi Jawa Tengah adalah kota kedua yang memiliki usia harapan hidup tinggi nomor dua setelah provinsi Yogyakarta dan memilih kota Magelang karena kota Magelang terdapat organisasi GOW (Gabungan Organisasi Wanita) yang keanggotaannya mencakup organisasi-organisasi lansia di Kota Magelang, Jawa Tengah. Waktu penelitian akan dilaksanakan bulan Januari 2020.

Penentuan jumlah sampel dalam penelitian ini menggunakan metode non-probability sampling dengan teknik pengumpulan data sampling jenuh merupakan penentuan sampel apabila semua anggota populasi digunakan menjadi sampel. Karena populasinya dianggap relatif sedikit, sehingga dianggap cukup untuk mewakili seluruhnya. Menurut Arikunto (2012) jika jumlah populasinya kurang dari 100 orang maka jumlah sampelnya diambil secara keseluruhan, tetapi jika populasinya lebih besar dari 100 orang maka bisa diambil $10-15 \%$ atau 20-25\% dari jumlah populasinya. Jumlah sampel pada penelitian ini berjumlah 54 responden. Teknik pengolahan data dan analisis data menggunakan SPSS dan Ms. Excel.

Pernyataan untuk setiap butir dalam kuisioner di ukur menggunakan skala likert dengan kusisioner tertutup yaitu 1 sampai dengan 4 poin, dalam hal ini untuk skala terendah yaitu 1 dan untuk skala tertinggi yaitu 4. Instrumen grandparenting style digunakan menurut (Deutsch dalam Herawati, Krinatuti, \& Alfiasari) yaitu tipe formal, tipe pencari kesenangan (fun-seeking), tipe orang tua pengganti (parent surrogant), tipe pemeliharaan nilai dalam keluarga (reservoir of family wisdom), dan tidak akrab (distant figure). Kemudian untuk variabel kesejahteraan psikologis digunakan menurut (WHOQOL-100) yaitu gambaran tubuh dan penampilan; perasaan negatif; perasaan positif; kepercayaan diri; berpikir, belajar, ingatan, dan konsentrasi.

\section{HASIL DAN PEMBAHASAN}

\section{Karakteristik Responden}

Responden dalam penelitian ini berusia 64-74 tahun yang merupakan anggota dari Gabungan Organisasi Wanita (GOW) Kota Magelang, Jawa Tengah. Keseluruhan responden berjumlah 54 orang. Berdasarkan gambar 2 seluruh jumlah responden adalah perempuan. Berikut merupakan diagram hasil karakteristik berdasarkan jenis kelamin:

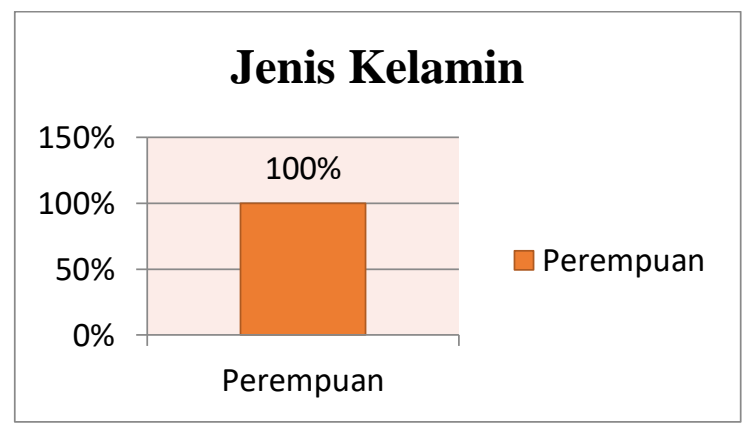

Gambar 2. Sebaran Jenis Kelamin 
Berdasarkan gambar 3 presentase responden yang berusia 64 tahun sebesar $5 \%$, usia 65 tahun sebesar $6 \%$, usia 66 tahun sebersar $6 \%$, usia 67 tahun sebesar $7 \%$, usia 68 tahun sebesar $5 \%$, usia 69 tahun sebesar $4 \%$, usia 70 tahun sebesar $8 \%$, usia 71 tahun sebesar $5 \%$, usia 72 tahun sebesar $2 \%$, usia 73 tahun sebesar $2 \%$, dan usia 74 tahun sebesar $4 \%$. Berikut merupakan gambar karakteristik responden dalam diagram sebaran usia responden:

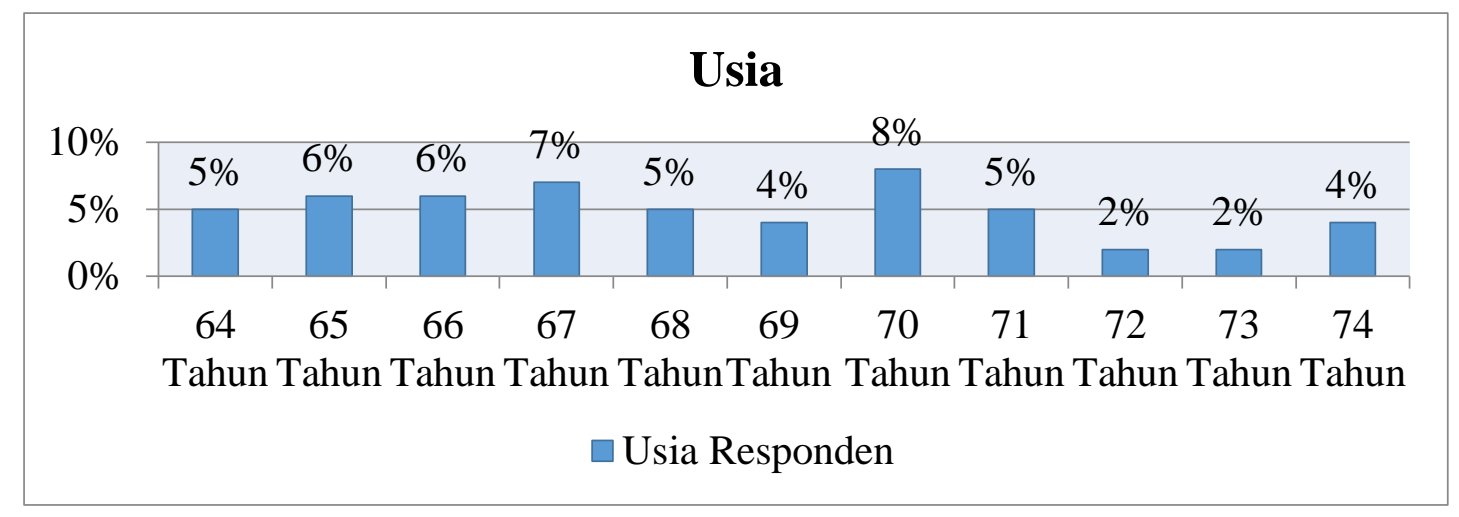

Gambar 3 Sebaran Usia Responden

Hasil penelitian menunjukkan (gambar. 4) lebih dari separuh (32\%) lansia yang aktif di GOW adalah pensiunan pegawai negeri sipil dan sebanyak $24 \%$ lansia bekerja sebagai guru, perawat dan tidak bekerja (ibu rumah tangga).

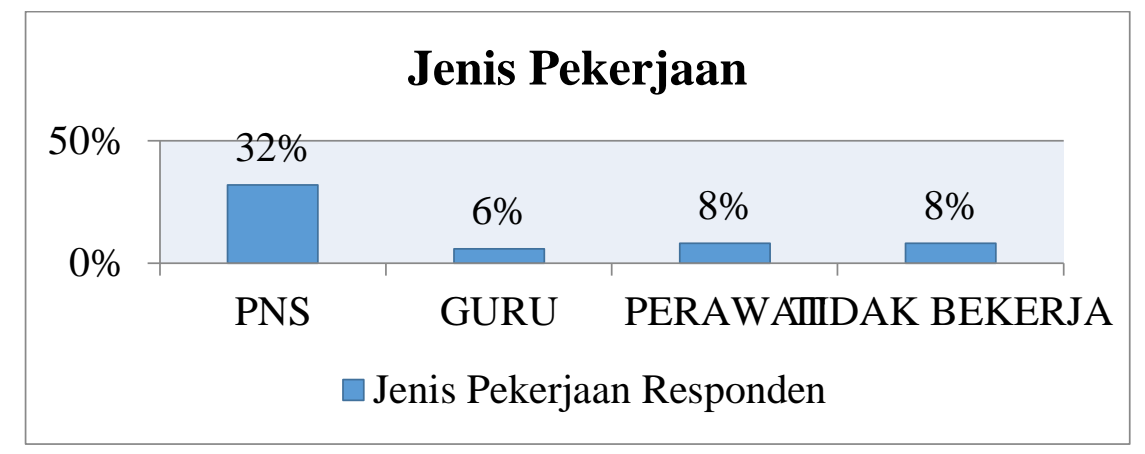

Gambar 4. Sebaran Jenis Pekerjaan Responden

Variabel Kesejahteraan Psikologis

Dimensi Gambaran Tubuh dan Penampilan Fisik

Tabel 1 Dimensi Gambaran Tubuh dan Penampilan Fisik

\begin{tabular}{|c|c|c|c|c|c|c|}
\hline \multirow{2}{*}{ No. } & \multirow{2}{*}{ Pernyataan } & \multicolumn{4}{|c|}{ Tanggapan Responden } & \multirow{2}{*}{ Total } \\
\hline & & 1 & 2 & 3 & 4 & \\
\hline 1. & Menikmati hidup & 0 & 9,3 & 46,3 & 44,4 & 100 \\
\hline 2. & $\begin{array}{l}\text { Memiliki rencana hidup di masa } \\
\text { mendatang. }\end{array}$ & 3,7 & 27,8 & 46,3 & 22,2 & 100 \\
\hline $\begin{array}{l}3 . \\
4 .\end{array}$ & $\begin{array}{l}\text { Selalu berpikir positif. } \\
\text { Merasa puas dengan kondisi . }\end{array}$ & $\begin{array}{l}5,6 \\
14,8\end{array}$ & $\begin{array}{l}22,2 \\
25,9\end{array}$ & $\begin{array}{l}53,7 \\
53,7\end{array}$ & $\begin{array}{l}18,5 \\
5,6\end{array}$ & $\begin{array}{l}100 \\
100\end{array}$ \\
\hline
\end{tabular}


Hasil penelitian menunjukkan lansia sebanyak $44.4 \%$ lansia dapat menikmati hidupnya $(44,4 \%)$. Hal ini selaras dengan yang dikemukan oleh Ryff dan Singer (1996) mengatakan sebagai individu dengan tujuan hidup yang tinggi telah menentukan target dan cita-cita yang akan dicapai serta merasa bahwa baik kehidupan masa lalu maupun sekarang adalah kehidupan yang bermakna.Dan sejalan juga dengan pendapat Huppert (2009) yang mengatakan lansia harus memiliki kondisi yang sejahtera secara psikologis juga menumbuhkan kondisi sehat yang positif agar terhindar dari berbagai penyakit.

\section{Dimensi Perasaan Negatif}

Tabel 2. Deskripsi Dimensi Perasaan Negatif

\begin{tabular}{clccccc}
\hline \multirow{2}{*}{ No. } & \multicolumn{1}{c}{ Pernyataan } & \multicolumn{4}{c}{ Tanggapan Responden } & \multirow{2}{*}{ Total } \\
\cline { 3 - 5 } & & 1 & 2 & 3 & 4 & \\
\hline 1. & Merasa cemas. & 0 & 14,8 & 31,5 & 53,7 & 100 \\
2. & Merasa tertekan yang menghambat & 5,6 & 18,5 & 20,4 & 55,6 & 100 \\
3. & Mulam beraktifitas. & 0 & 18,5 & 24,1 & 57,4 & 100 \\
\hline Keterangan : Selalu (4), Sering (3), Kadang-Kadang (2), Tidak Pernah (1) & & &
\end{tabular}

Dimensi perasaan negatif merupakan aspek yang mengukur seberapa besar perasaan negatif yang dimiliki oleh lansia misalnya mudahnya merasa cemas dan tertekan sehingga dapat menghambat aktifitas sehari-hari lansia. Hasil penelitian menunjukkan sebanyak $57.4 \%$ lansia mudah tertekan oleh kejadian maupun sikap tertentu. Seperti yang tercantum dalam UU No. 13 Tahun 1998 Pasal 1, menyatakan bahwa kesejahteran lansia diliputi oleh rasa keselamatan, kesusilaan, dan ketentraman lahir dan batin karena kesejahteraan merupakan harapan dan tujuan hidup semua orang. Hal ini sejalan dengan pendapat Huppert (2009) konsep perasaan baik tidak hanya menggabungkan emosi positif seperti kebahagiaan dan kepuasan terhadap sesuatu namun juga pengalaman emosi negatif, tetapi jika pengalaman emosi negatif yang dialami oleh lansia berlangsung untuk waktu yang cukup lama maka akan mengganggu kesejahteraan dan keberfungsian lansia dalam kehidupannya

\section{Dimensi Perasaan Positif}

Positif Dimensi perasaan positif mengukur seberapa besar perasaan positif yang dimiliki lansia seperti percaya pada diri sendiri dan mengetahui kemampuan yang dimiliki dalam mengevaluasi diri secara positif. Hasil penelitian menunjukkan perasaan postif lansia mempnyai hasil $51.9 \%$ pada pernyataab merasa percaya diri (tabel.3)

Tabel 3. Dimensi Perasaan Positif

\begin{tabular}{|c|c|c|c|c|c|c|}
\hline \multirow{2}{*}{ No. } & \multirow{2}{*}{ Pernyataan } & \multicolumn{4}{|c|}{ Tanggapan Responden } & \multirow{2}{*}{ Total } \\
\hline & & 1 & 2 & 3 & 4 & \\
\hline 1. & Pribadi yang baik. & 0 & 33,7 & 46,3 & 16,7 & 100 \\
\hline 2. & Percaya pada diri sendiri. & 1,9 & 24,1 & 51,9 & 22,2 & 100 \\
\hline 3. & $\begin{array}{l}\text { Puas dengan kemampuan yang saya } \\
\text { miliki. }\end{array}$ & 9,3 & 22,2 & 40,7 & 27,8 & 100 \\
\hline
\end{tabular}

Keterangan: Selalu (4), Sering (3), Kadang-Kadang (2), Tidak Pernah (1)

Hal ini sejalan yang dikemukan oleh Ryff dan Singer (1996) menyatakan individu yang memiliki nilai positif pada hubungan positif dengan orang lain digambarkan sebagai seseorang yang memiliki kemampuan membangun hubungan yang hangat, membangun kepercayaan dengan orang lain, memiliki rasa empati dan perhatian yang tinggi kepada orang lain. 


\section{Dimensi Kepercayaan Diri}

Dimensi kepercayaan diri mengukur kemampuan untuk mengakui aspek dari diri sendiri seperti merasa nyaman dengan penampilan fisik diri lansia dalam kegiatan sehari-hari bersama dengan cucu maupun di kegiatan formal organisasi maupun kegiatan lainnya.

Tabel 4 Dimensi Kepercayaan diri

\begin{tabular}{|c|c|c|c|c|c|c|}
\hline \multirow[b]{2}{*}{ No. } & \multirow[b]{2}{*}{ Pernyataan } & \multicolumn{4}{|c|}{ Tanggapan Responden } & \multirow[b]{2}{*}{ Total } \\
\hline & & 1 & 2 & 3 & 4 & \\
\hline 1. & Menyukai penampilan saat ini. & 7,4 & 9,3 & 25,9 & 57,4 & 100 \\
\hline 2. & $\begin{array}{l}\text { Penampilan membuat saya merasa tidak } \\
\text { nvaman. }\end{array}$ & 7,4 & 22,2 & 22,2 & 48,1 & 100 \\
\hline 3. & Puas dengan penampilan fisik saya saat ini. & 5,6 & 24,1 & 24,1 & 46,3 & 100 \\
\hline
\end{tabular}

Hasil penelitian menunjukkan $57.4 \%$ para lansia merasa percaya diri sesuai dengan pertanyaan menyukai penampilan saat ini. ketika individu yang memiliki penguasaan lingkungan yang baik akan menunjukkan kemampuan untuk memanipulasi, mengontrol, dan dapat menggunakan sumber daya dan kesempatan yang ada dengan efektif dan membuat lansia lebih percaya diri karena sudah bisa memiliki penguasaan diri yang baik dan terintegrasi agar tidak mengalami konflik internal di dalam diri. Hal ini sejalan dengan penelitian sebelumnya yang menyatakan bahwa konsep kesejahteraan adalah sesuatu yang bersifat subjektif dimana setiap orang mempunyai pedoman, tujuan dan cara hidup yang berbedabeda sehingga memberikan nilai-nilai yang berbeda pula tentang faktor-faktor yang menentukan tingkat kesejahteraan dari setiap individu. (Andriani ,2009)

\section{Dimensi Berpikir, Belajar, Ingatan dan Konsentrasi}

Dimensi berpikir, belajar, ingatan, dan konsentrasi adaah untuk mengukur tingkat kemampuan lansia dalam berpikir untuk perasaan yang dirasakan diri sendiri, kemampuan lansia dalam belajar tentang perasaan diri sendiri, kemampuan lansia dalam mengingat tentang perasaan yang pernah dirasakan, kemampuan lansia dalam berkonsentrasi dengan perasaan yang sedang dirasakan

Hasil penelitian menunjukkan sebagian besar responden $(25,9)$ memiliki konsentrasi yang baik. Hal ini sejalan yang dikemuakan oleh Erikson dalam Papalia dkk (2007) dalam usia dewasa madya, individu dapat mencapai suatu tahapan normatif yang disebut dengan generativity. Generativity merupakan sebuah tahapan dimana seseorang mengembangkan perhatiannya untuk memandu dan memberi pengaruh kepada generasi selanjutnya (Tabel. 5).

Tabel 5. Dimensi berpikir, belajar, ingatan, dan konsentrasi

\begin{tabular}{|c|c|c|c|c|c|c|}
\hline \multirow{2}{*}{ No. } & \multirow{2}{*}{ Pernyataan } & \multicolumn{4}{|c|}{ Tanggapan Responden } & \multirow{2}{*}{ Total } \\
\hline & & 1 & 2 & 3 & 4 & \\
\hline 1. & Memiliki konsentrasi yang baik. & 5,6 & 29,6 & 38,9 & 25,9 & 100 \\
\hline 2. & $\begin{array}{l}\text { Puas dengan kemampuan saya dalam } \\
\text { belaiar tentana informasi baru }\end{array}$ & 3,7 & 25,9 & 57,4 & 13,0 & 100 \\
\hline 3. & Memiliki Ingatan yang baik. & 5,6 & 22,2 & 55,6 & 16,7 & 100 \\
\hline
\end{tabular}




\section{Variabel Grandparenting Style}

\section{Dimensi Formal}

Dimensi Formal untuk mengukur kejelasan peran di antara cucu dan nenek (lansia), mengukur jarak antara cucu dan nenek (jarak kedekatan atau intens melakukan interaksi), serta menjunjung rasa hormat kepada lansia. Sebaran responden berdasarkan tanggapan untuk pernyataan dimensi berpikir, belajar, ingatan dan konsentrasi.

Tabel 6. Dimensi Formal

\begin{tabular}{llr|r|r|r}
\hline & \multicolumn{2}{c}{ Frequency } & Percent & Valid Percent & \multicolumn{2}{c}{$\begin{array}{c}\text { Pumulative } \\
\text { Percent }\end{array}$} \\
\hline \multirow{2}{*}{ Valid } & Rendah & 4 & 7.4 & 7.4 & 7.4 \\
\cline { 2 - 6 } & Sedang & 41 & 75.9 & 75.9 & 83.3 \\
\cline { 2 - 6 } & Tinggi & 9 & 16.7 & 16.7 & 100.0 \\
\cline { 2 - 6 } & Total & 54 & 100.0 & 100.0 & \\
\hline
\end{tabular}

Hasil penelitian menunjukkan dimensi formal pada tingkat sedang, hal ini sejalan dengan penelitian Herawati, Krinatuti, dan Alfiasari (2013) bahwa peran dan jarak yang jelas antara tanggung jawab parenting orang tua dan lansia (nenek), menjaga kesimbangan yang baik antara peran orang tua dan peran nenek dengan mendengarkan ketika dibutuhkan, dan mendorong hubungan antara orang tua dan anak.

\section{Dimensi Pencari Kesempatan}

Dimensi pencari kesenangan untuk mengukur seberapa besar lansia (nenek) memanjakan cucu, memberi kebebasan kepada cucu, tidak mampu menolak permintaan cucu, dan melakukan kegiatan yang menyenangkan bersama cucu.

Tabel 7. Dimensi Pencari Kesenangan

\begin{tabular}{|c|c|c|c|c|c|}
\hline & & Frequency & Percent & Valid Percent & $\begin{array}{c}\text { Cumulative } \\
\text { Percent }\end{array}$ \\
\hline \multirow[t]{4}{*}{ Valid } & Rendah & 14 & 25.9 & 25.9 & 25.9 \\
\hline & Sedang & 37 & 68.5 & 68.5 & 94.4 \\
\hline & Tinggi & 3 & 5.6 & 5.6 & 100.0 \\
\hline & Total & 54 & 100.0 & 100.0 & \\
\hline
\end{tabular}

Berdasarkan hasil penelitian menunjukkan dimensi pencari kesenangan mempunyai presentase $(68.5 \%)$ dan masuk dalam katagori sedangm hal ini sejalan yang dikemukan oleh Sunarti dkk (1989) dikutip oleh Manasari (2013) bahwa mengasuh meliputi menjaga serta membimbing dalam pertumbuhan anak ke arah kedewasaan dengan memberikan pendidikan, makanan, dan perlu memastikan bahwa mereka tidak melelahkan diri mereka saat melakukan kegiaitan yang menyenangkan bersama cucu.

\section{Dimensi Orang Tua Pengganti}

Dimensi orang tua pengganti adalah untuk mengukur responden (lansia) bertanggung jawab dalam memberikan pengasuhan, memberikan perhatian seutuhnya, dan menanamkan disiplin diri pada cucu. 
Tabel 8. Dimensi Orang Tua Pengganti

\begin{tabular}{|c|c|c|c|c|c|}
\hline & & Frequency & Percent & Valid Percent & $\begin{array}{c}\text { Cumulative } \\
\text { Percent }\end{array}$ \\
\hline \multirow[t]{3}{*}{ Valid } & Rendah & 24 & 44.4 & 44.4 & 44.4 \\
\hline & Sedang & 30 & 55.6 & 55.6 & 100.0 \\
\hline & Total & 54 & 100.0 & 100.0 & \\
\hline
\end{tabular}

Hasil penelitian menunjukkan dimensi orangtua pengganti dalam katagori sedang (55.6\%). Hal ini menunjukkan bahwa lansia menghormati peraturan yang di buat oleh orang tuanya dalam hal pengasuhan, nenek tidak membuat peraturan baru untuk mengasuh dan mengikuti apa yang sudah menjadi peraturan yang dimiliki oleh orang tuanya sejalan dengan Brooks dalam Arismanto (2008) dikutip oleh Rahmawati (2015) mengemukakan bahwa figur nenek atau kakek (grandparents) menjadi pengasuh utama bagi anak-anak yang penuh tanggung jawab dalam menggantikan tugas orang tua mereka, salah satu alasan pengasuhan oleh nenek atau kakek dipilih karena orang tua tidak memiliki waktu yang cukup untuk mengasuh anak, seperti orang tua bekerja sampai larut malam.

\section{Dimensi Menjaga Nilai Keluarga}

Dimensi menjaga nilai dalam keluarga untuk mengukur responden (lansia) dalam memperhatikan nilai dan tradisi leluhur dan menerapkan nilai-nilai dalam keluarga. Sebaran responden berdasarkan tanggapan untuk pernyataan dimensi menjaga nilai dalam keluarga. Berdasarkan hasil penelitian menunjukkan pada dimensi menjaga nilai dalam keluarga, nulai tertinggi ada pada pernyataan "Mengawasi cucu saya untuk berperilaku sesuai dengan nilainilai keluarga" sebesar (16.7\%) hal tersebut sesuai dengan pendapat Herawati, Krinatuti, \& Alfiasari (2013) dalam menjaga nilai di keluarga dapat menyalurkan keterampilan khusus atau sumber-sumber yang diperlukan untuk dapat memberikan serta menanamkan nilai-nilai dalam keluarga kepada cucu agar bisa menghormati batas dan tidak melangkahi hubungan antara orang tua dan anak.

Tabel 9. Dimensi Menjaga Nilai Keluarga

\begin{tabular}{|c|c|c|c|c|c|c|}
\hline \multirow{2}{*}{ No. } & \multirow{2}{*}{ Pernyataan } & \multicolumn{4}{|c|}{ Tanggapan Responden } & \multirow{2}{*}{ Total } \\
\hline & & 1 & 2 & 3 & 4 & \\
\hline 1. & $\begin{array}{l}\text { Sangat memperhatikan nilai dan budaya } \\
\text { daerah tanah kelahiran. } \\
\text { Menceritakan nilai dan tradisi kepada cucu }\end{array}$ & 14,8 & 31,5 & 42,6 & 11,1 & 100 \\
\hline 2. & $\begin{array}{l}\text { saya pada waktu dulu ketika seusia dengan } \\
\text { cucu saya. }\end{array}$ & 22,2 & 37,0 & 25,9 & 14,8 & 100 \\
\hline 3. & $\begin{array}{l}\text { Melihat bahwa cucu saya mengikuti nilai- } \\
\text { nilai yang diterapkan di keluarga saat } \\
\text { tinggal bersama. }\end{array}$ & 18,5 & 44,4 & 29,6 & 7,4 & 100 \\
\hline 4. & $\begin{array}{l}\text { Mengawasi cucu saya untuk berperilaku } \\
\text { sesuai dengan nilai-nilai keluarga. }\end{array}$ & 11,1 & 25,9 & 46,3 & 16,7 & 100 \\
\hline 5. & $\begin{array}{l}\text { Membiarkan cucu saya berbuat seenaknya } \\
\text { di rumah. }\end{array}$ & 9,3 & 35,2 & 42,6 & 13,0 & 100 \\
\hline
\end{tabular}

\section{Dimensi Tidak Akrab}

Dimensi tidak akrab untuk mengukur kurangnya interaksi di antara responden (lansia) dengan cucu dan lansia tidak memperhatikan cucu mereka. 
Tabel 10 Dimensi Tidak Akrab

\begin{tabular}{clccccc}
\hline \multirow{2}{*}{ No. } & \multicolumn{1}{c}{ Pernyataan } & \multicolumn{3}{c}{ Tanggapan Responden } & \multirow{2}{*}{ Total } \\
\cline { 2 - 5 } & \multicolumn{1}{c}{$\begin{array}{l}\text { Hanya berbicara dengan cucu saya } \\
\text { 1. }\end{array}$} & 11,1 & 35,2 & 29,6 & 24,1 & 100 \\
jika ada keperluan saja. & $\begin{array}{l}\text { Merasa cucu saya tidak nyaman } \\
\text { berada di dekat saya. }\end{array}$ & 16,7 & 27,8 & 50,0 & 5,6 & 100 \\
\hline
\end{tabular}

Hasil penelitian menunjukkan $24.1 \%$ lansia hanya berbicara dengan cucu apabila ada keperluan saja. \%). Hal ini menunjukkan bahwa lansia tidak berbicara dengan cucu mereka ketika tidak ada hal atau keperluan yang harus dibicarakan dengan cucu mereka sejalan sengan penelitian Cherlin dan Furstenberg (1985) yang menyatakan bahwa pengasuhan yang memiliki kekurangan dalam berkomunikasi dengan cucu serta memainkan peran yang sangat kecil dalam kehidupan cucu mereka karena tidak mengasuh secara langsung.

\section{Hubungan Grandparenting Style dengan Kesejahteraan Psikologis Lansia}

Hasil penelitian menunjukkan nilai koefisien korelasi yaitu 0,452 >0,2262. Interpretasi korelasi dari hasil tersebut menunjukkan bahwa adanya hubungan positif signifikan grandparenting style dengan kesejahteraan psikologis pada lansia. Korelasi positif berarti, semakin tinggi kesejahteraan psikologis pada lansia semakin tinggi tingkat grandparenting style di Gabungan Organisasi Wanita (GOW) Kota Magelang, Jawa Tengah. Hasil penelitian ini mendukung temuan Huppert (2009) bahwa memiliki kondisi yang sejahtera secara psikologis juga menumbuhkan kondisi sehat yang positif terhindar dari berbagai penyakit yang ditimbulkan. Hasil ini juga sejalan dengan pendapat Cherlin dan Furstenberg (1985) gaya pengasuhan nenek atau kakek akan berdampak pada perkembangan anak, sama halnya dengan pengasuhan yang dilakukan oleh kedua orang tua dan menciptakan interaksi antara nenek dengan cucu sebagai pengasuh pengganti. Dengan demikian, grandparenting style yang diterapkan oleh lansia dapat menentukan kesejahteraan psikologis pada lansia.

Gaya pengasuhan (grandparenting style) merupakan cara berinteraksi antara lansia (nenek) dengan cucu. Grandparenting style terdiri dari unsur formal, pencari kesenangan, orang tua pengganti, menjaga nilai dalam keluarga, dan tidak akrab. Formal berdasarkan hasil sebaran jawaban responden menunjukkan bahwa sebagian besar lansia menggantikan peran sebagai orang tua pengganti bagi cucu mereka, seperti kejelasan peran di antara cucu dan nenek (lansia), jarak antara cucu dan nenek (jarak kedekatan atau intens melakukan interaksi), serta menjunjung rasa hormat kepada lansia. Pencari kesenangan berdasarkan hasil sebaran jawaban responden menunjukkan bahwa membebaskan cucu untuk membeli jajanan atau mainan di lingkungan rumah, tidak mempermasalahkan keinginan cucu untuk memakan makanan manis yang berlebihan, dan lansia cepat merasa bosan atau tidak tertarik ketika melakukan kegiatan bersama dengan cucu mereka, seperti seberapa besar lansia (nenek) memanjakan cucu, memberi kebebasan kepada cucu, tidak mampu menolak permintaan cucu, dan melakukan kegiatan yang menyenangkan bersama cucu. Orang tua pengganti berdasarkan hasil sebaran jawaban responden menunjukkan bahwa menghormati peraturan yang di buat untuk cucu oleh orang tuanya dalam mengasuh, seperti lansia bertanggung jawab dalam memberikan pengasuhan, memberikan perhatian seutuhnya, dan menanamkan disiplin diri pada cucu. Menjaga nilai dalam keluarga berdasarkan hasil sebaran jawaban responden menunjukkan bahwa cucu untuk berperilaku sesuai dengan nilai-nilai keluarga, seperti lansia dalam memperhatikan nilai dan tradisi leluhur dan menerapkan nilai-nilai dalam keluarga. Tidak akrab berdasarkan hasil sebaran jawaban responden menunjukkan bahwa hanya berbicara dengan cucu jika ada keperluan saja, seperti kurangnya interaksi di antara responden (lansia) dengan cucu dan lansia tidak memperhatikan cucu mereka. Hasil penelitian juga menunjukkan bahwa sebagian besar dari 54 lansia $(75,9 \%)$ dengan tingkat 
sedang menerapkan gaya pengasuhan formal. Menurut Herawati, Krinatuti, \& Alfiasari (2013) lansia dengan tipe pengasuhan formal memiliki peran tradisional seperti menjadi pendukung latar belakang bagi orang tua dan anak-anak (cucu).

Kesejahteraan psikologis menurut UU No. 13 Tahun 1998 Pasal 1 adalah suatu tata kehidupan dan penghidupan sosial baik material maupun spiritual yang diliputi oleh rasa keselamatan, kesusilaan, dan ketenteraman lahir batin yang memungkinkan bagi setiap warga negara untuk mengadakan pemenuhan kebutuhan jasmani, rohani, dan sosial yang sebaikbaiknya bagi diri, keluarga, serta masyarakat dengan menjunjung tinggi hak dan kewajiban asasi manusia sesuai dengan Pancasila. Kesejahteraan psikologis terdiri dari unsur gambaran tubuh dan penampilan fisik; perasaan negatif; perasaan positif; kepercayaan diri; berpikir, belajar, ingatan, dan konsentrasi. Gambaran tubuh dan penampilan fisik berdasarkan hasil sebaran jawaban responden menunjukkan bahwa sebagian besar lansia menikmati hidupnya, seperti menerima gambaran tubuh dan penampilan fisik. Perasaan negatif berdasarkan hasil sebaran jawaban responden menunjukkan bahwa sebagian besar lansia mudah tertekan, seperti mengevaluasi diri secara negatif. Perasaan positif berdasarkan hasil sebaran jawaban responden menunjukkan bahwa sebagian besar lansia puas dengan kemampuan yang saya miliki, seperti mengevaluasi diri secara positif. Kepercayaan diri berdasarkan hasil sebaran jawaban responden menunjukkan bahwa sebagian besar lansia menyukai penampilannya saat ini, seperti mengakui aspek dari diri dan menerima baik positif atau negatif dari diri lansia. Berpikir, belajar, ingatan, dan konsentrasi berdasarkan hasil sebaran jawaban responden menunjukkan bahwa sebagian besar lansia memiliki konsentrasi yang baik, seperti berpikir untuk perasaan yang dirasakan, belajar tentang perasaan diri, mengingat tentang perasaan yang pernah dirasakan diri, berkonsentrasi dengan perasaan yang dimiliki. Hasil penelitian juga menunjukkan bahwa sebagian besar dari 54 lansia $(66,7 \%)$ dengan tingkat tinggi menerapkan dimensi berpikir, belajar, ingatan, dan konsentrasi. Menurut Ryff (dalam Ryan \& Deci, 2001), menyatakan bahwa kesejahteraan psikologis tidak hanya sebatas perolehan akan kesenangan, namun merupakan usaha individu untuk mencapai kesempurnaan yang menggambarkan kesadaran akan potensi dalam dirinya. Hasil peneletian diatas juga di dukung oleh penelitian Mulyati (2012) konsep kesejahteraan adalah sesuatu yang bersifat subjektif dimana setiap orang mempunyai pedoman, tujuan dan cara hidup yang berbedabeda sehingga memberikan nilai-nilai yang berbeda pula tentang faktor-faktor yang menentukan tingkat kesejahteraan.

Berdasarkan uji signifikansi korelasi (Uji-t) hasil perhitungan diketahui bahwa thitung sebesar 3,65 dengan $t_{\text {tabel }}$ sebesar 1,675. Hasil tersebut dapat diartikan bahwa data berkorelasi signifikan antara hubungan grandparenting style terhadap kesejahteraan psikologis lansia. Hal ini berarti bahwa terdapat hubungan yang kuat dan signifikan antara hubungan grandparenting style dengan kesejahteraan psikologis lansia. Hasil penelitian dapat diketahui bahwa ada hubungan positif dan signifikan antara grandparenting style dengan kesejahteraan psikologis lansia pada Gabungan Organisasi Wanita (GOW) Kota Magelang, Jawa Tengah. Hasil ini menunjukkan apabila grandparenting style tinggi, maka akan tinggi pula kesejahteraan psikologis lansia begitupun sebaliknya. Dengan demikian hipotesis yang dinyatakan ada hubungan positif dan signifikan antara grandparenting style dengan kesejahteraan psikologis lansia pada Gabungan Organisasi Wanita (GOW) Kota Magelang, Jawa Tengah.

Hasil penelitian diatas didukung oleh penelitian Purnomo (2009) yang menunjukkan bahwa dukungan sosial memberikan kontribusi yang tinggi terhadap kesejahteraan psikologis (psychological well-being) lansia di Panti Werdha "X" Bandung. Hasil penelitian juga didukung dengan penelitian yang dilakukan oleh Ria (2016) "Pola Asuh Grandparenting (Studi pada 5 Keluarga di Desa Wukisari, Imogiri, Bantul)" Hasil penelitian diketahui bahwa pengasuhan kakek-nenek disebabkan oleh faktor orang tua bekerja dan perceraian sehingga pola asuh yang diterapkan pada 5 keluarga di Desa Wukirasari yaitu pola asuh demokratis, otoriter, dan permisif. Pola asuh grandparenting yang dilakukan oleh kakek-nenek di desa tersebut 
merupakan pola asuh yang biasa, namun yang membedakan hanya gaya pengasuhan. Begitu juga hasil penelitian yang menunjukkan bahwa oleh Fonds (2015) dengan judul: "Gambaran Kesejahteraan Psikologis Pada Wanita Dewasa Madya Ditinjau Dari Grandparenting Style" hasil penelitian menunjukkan bahwa berdasarkan rata-rata skor kesejahteraan psikologis, grandparenting style companionate $(X=56.00)$ dan involve $(X=55.32)$ tergolong dalam kategori tingkat kesejahteraan psikologis tinggi, sedangkan grandparenting style remote $(X=51.87)$ tergolong dalam kategori tingkat kesejahteraan psikologis sedang.

Berdasarkan uraian di atas, menunjukkan bahwa grandparenting style berhubungan dengan kesejahteraan psikologis. Hal ini sesuai dengan penelitian yang dilakukan oleh Fonds (2015) dimana ketika seorang lansia memiliki tingkat grandparenting style yang tinggi dalam pengasuhan kepada cucu mereka, maka mereka akan cenderung mendapatkan kesejahteraan psikologis dari menambahkan dalam kegiatan sehari-hari mereka adalah berinteraksi dengan kasih sayang terhadap cucu mereka dan tidak memforsir diri mereka karena kesejahteraan merupakan harapan dan tujuan hidup bagi setiap orang.

Hasil penelitian semakin menguatkan bahwa kesejahteraan psikologis ini memiliki keterkaitan dengan grandparenting style. Semakin baik kesejahtetaan psikologis maka semakin baik pula grandparenting style lansia. Dengan demikian, untuk meningkatkan kualitas grandparenting style maka perlu juga melakukan peningkatan kualitas kesejahteraan psikologis. Hasil penelitian yang dilakukan oleh Desiningrum (2015) menunjukkan bahwa salah satu cara yang dapat dilakukan untuk meningkatkan kualitas kesejahteraan psikologis pada lansia adalah dengan cara pemberian dukungan sosial. Dukungan social yang dimaksud tidak hanya dari keluarga, namun juga bisa dari teman sebaya. Dukungan dari teman sebaya berbeda bergantung pada bentuk dukungan teman sebaya yang diperoleh. Lansia yang memiliki kesejahteraan psikologis yang tinggi adalah lansia yang berada pada kelompok informational support (Simanjuntak \& Sulistyaningsih, 2018).

\section{SIMPULAN DAN SARAN}

Temuan ini menegaskan bahwa gaya pengasuhan nenek (grandparenting style) yang tinggi menunjukkan tingkat kesejahteraan psikologis yang timggi pula. Tingginya kesejahteraan psikologis dapat disebabkan oleh pengasuhan nenek yang dilakukan secara optimal dalam memberikan perhatian, memahami peran sebagai orang tua pengganti, dan kontrol yang seimbang di antara nenek dan juga cucu. Sebagian besar nenek termasuk kedalam grandparenting style dengan kategori tinggi, hal ini berarti Sebagian besar nenek telah menerapkan gaya pengasuhan yang optimal. Namun, ada sebagian besar ditemukan nenek menerapkan gaya pengasuhan dimensi tidak akrab merupakan dimensi terendah yang akan berdampak negatif pada diri lansia dan membuat lansia tidak dapat memiliki hubungan yang akrab dengan cucu nya. Hasil uji signifikansi korelasi (Uji-t) hasil perhitungan diketahui bahwa thitung sebesar 3,65 dengan $t_{\text {tabel }}$ sebesar 1,675. Hasil tersebut dapat diartikan bahwa data berkorelasi signifikan antara hubungan grandparenting style terhadap kesejahteraan psikologis lansia. Hal ini berarti bahwa terdapat hubungan yang kuat dan signifikan antara hubungan grandparenting style dengan kesejahteraan psikologis lansia. Variabel grandparenting style berhubungan kesejahteraan psikologis sebesar $20,4 \%$, sedangkan $79,6 \%$ sisanya berhubungan dengan faktor lain yang tidak diteliti dalam penelitian ini.

\section{DAFTAR PUSTAKA}

Arikunto, S. (2013). Prosedur Penelitian: Suatu Pendekatan Praktik. Rineka Cipta.

Arismanto. (2008). Tinjauan Berbagai Aspek: Character Building (Bagaimana Mendidik Anak Berkarakter). Yogyakarta: Tiara Wacana.

BPS. (2000). Statistika Indonesia (Statistical Year Book of Indonesia). BPS. 
BPS. (2018). Kota Magelang Dalam Angka 2018. BPS Kota Magelang.

Cherlin, J. Andrew \& Furstenberg, F. F. (1985). The New American Grandparent: A Place in the Family, A Life Apart. Harvard University.

Desiningrum, D. R. (2015). Kesejahteraan Psikologis Lansia Janda/Duda Ditinjau dari Persepsi Terhadap Dukungan Sosial dan Gender. Jurnal Psikologi, 13(2), $102-$ 106. https://doi.org/10.14710/jpu.13.2.102-201

Herawati, P., Krisnatuti, K., \& Alfiasari. (2013), Interaksi Dengan Cucu, Kualitas Perkembangan Dan Gejala Stress Pada Kakek/Nenek. Jurnal IImu Keluarga dan Konsumen, 6(1), 1-9.

Huppert, F. A. (2009). Psychological Well-being: Evidence Regarding its Causes and Consequences. Journal compilation International Association of Applied Psychology: Health and Well-Being, 1 (2), 137-164.

Koentjaraningrat. (1997). Manusia dan Kebudayaan di Indonesia. Penerbit Djambatan.

Mulyati. (2012). Dukungan Sosial dan Ekonomi Keluarga Terhadap Kualitas Hidup dan Kesejahteraan Lansia di Kota Bogor [tesis]. Institut Pertanian Bogor.

Papalia, D. E., Sterns, H. L., Fieldman, R.D. \& Camp, C.J. (2007). Adult Development And Aging. New York: McGraw Hill.

Purnomo, Akhmad. (2009). Kepuasan Hidup dan Dukungan Sosial Lanjut Usia. Yogyakarta: B2P3KS Press.

Ryan, R. M. \& Deci, E. L. (2001). On Happiness and Human Potentials: A Review of Research on Hedonic and Eudaimonic Well-Being. Annual Review of Psychology, 52, 141-166. doi: 10.1146/annurev.psych.52.1.141.

Ryff, C. D., \& Singer, B. H. (1996). Psychological well-being: meaning, measurement, and implications for psychotherapy research. Psychother Psychom, 65, 14-23.

Simanjuntak, L.S., \& Sulistyaningsih. (2018). Perbedaan kesejahteraan psikologis lansia ditinjau dari bentuk dukungan teman sebaya. Psikologia: Jurnal Pemikiran \& Penelitian Psikologi, 13(2), 59-73.

Syamsu, Y. (2006). Perkembangan Anak dan Remaja. PT. Rhineka Cipta. 